\title{
Morphological, Cultural and Pathological Variability of Moesziomyces penicillariae (Bref) Vanky isolates, the Incitant of Pearl Millet Smut
}

\author{
Annie Khanna*, Kushal Raj, Pooja Sangwan and Narender Singh \\ Department of Plant Pathology, College of Agriculture, \\ Chaudhary Charan Singh Haryana Agricultural University, \\ Hisar 125004, Haryana, India \\ *Corresponding author
}

\section{A B S T R A C T}

\section{Keywords \\ Moesziomyces penicillariae, pearl millet, smut, variability}

\section{Article Info}

Accepted:

30 April 2018

10 June 2018
Available Online:

\begin{abstract}
Among four isolates of Moesziomyces penicillariae the incitant of pearl millet smut, cultural, morphological and pathogenic variability was studied. The isolates were collected from four different pearl millet growing regions of India. Among the four isolates no variation was observed in size of spore balls but significant variation was observed in their germination percentage. Out of the six different media used, potato dextrose agar medium enriched with $50 \mathrm{~g}$ pearl millet grain and $20 \mathrm{~g}$ sucrose supported maximum growth of the fungus and least growth was observed in oat meal agar. In order to elucidate pathogenic variability pathogenic test was performed by artificial inoculation and it was observed that the highest smut severity was recorded in HHB67(Improved) followed by HHB226 and minimum smut severity was recorded in HHB197 followed by RHB177.Based on the study it was concluded that the isolates differ in virulence and isolate Mp2 was the most virulent.
\end{abstract}

\section{Introduction}

Pearl millet (Pennisetum glaucam (L.) R. Br.) is the important summer annual crop for the population living in drought prone arid and semi arid regions of less developed countries in the world and well suited for double cropping and rotation. It is grown in Africa and Indian subcontinent since prehistoric times. The earliest record in India dates back to 2000 BC (Fuller, 2003). Pearl millet is well adapted to growing areas characterized by drought, low soil fertility and high temperature and it performs well in soil with high salinity or low $\mathrm{pH}$.
It has tremendous potential to add to the food basket. Smut caused by Moesziomyces penicillariae is one of the major production constraints. The disease is severe when humid weather prevails during inflorescence emergence (Ajrekar and Likhite, 1933; Bhatt, 1946). The disease may cause losses in yield upto 30 per cent, 20.6 percent and 22.8 per cent (Ramkrishanan, 1963). Keeping in view the variation in smut severity in different areas and varieties the studies have been conducted to determine the morphological, cultural and pathogenic variation among different isolates of $M$. penicillariae. 


\section{Materials and Methods}

Four isolates of Moesziomyces penicillariae were collected from the different pearl millet growing zones of India viz., Jaipur, Hisar, Gwalior and Mandore and were designated as Mp1, Mp2, Mp3 and Mp4. Smutted ear heads from each location were collected by the end of the September and those earheads were sundried properly and then sealed in polythene bags and were preserved at $6 \pm 1{ }^{\circ} \mathrm{C}$ in cool and dry place throughout the duration of the study. The morphological character in respect of sporeballs size, colour, shape and germination per cent of each isolate were examined. Mature smut sori were crushed and sporeballs were mounted on a drop of water on a clean glass slide. The size of fifty sporeballs was examined under compound microscope (10X) for colour, size and shape. For studying the spore germination, moisture chambers were prepared. Petri plates were lined by moist Whatman filter paper of $90 \mathrm{~mm}$ and sporeballs of all the four isolates were suspended in sterlised distilled water in cavity slides. The cavity slides were kept in moist chambers at $30^{\circ} \mathrm{C}$. For each isolate two replications were maintained. Observations on per cent spore germination were recorded after $24 \mathrm{~h}$ of incubation (SubhaRao and Thakur, 1983).

Based upon morphological observations cultural study was carried out for the most virulent isolate i.e. Hisar isolate. Different media viz., PDA, PDA medium enriched with three different concentration of pearl millet grains i.e. 25,50 and $100 \mathrm{~g} / \mathrm{L}$ and sucrose @ $20 \mathrm{~g} / \mathrm{L}$, oat meal agar and Czapekdox agar medium were used to study their effect on growth of M. penicillariae (Hisar isolate) with four replications. Petri plates were incubated at $35^{\circ} \mathrm{C}$ and observations were recorded for colour, type of growth and mean colony diameter at weekly interval until the plates were full.

Pathogenicity test was conducted in order to elucidate the pathogenic variability in $M$. penicillariae. Four popular pearl millet cultivars viz., HHB 67 Improved, HHB 197, HHB 226 and RHB 177 given in Table 1 were inoculated with Mp1, Mp2, Mp3 and Mp4isolate by maintaining identical environmental conditions under field conditions. Inoculations were done at earhead emergence stage using same amount of sporidial aqueous solution. Ten earheads of each cultivar, with three replications were tagged for inoculation with each isolate. Immediately after inoculation earheads were covered with the parchment paper bags and labeled. Overhead sprinkler irrigation was provided daily to maintain high humidity. Earheads of each cultivar were scored after 15 to 20 days of inoculation, for smut severity using standard smut severity (\%) rating scale as given by Thakur and King, 1988.

\section{Results and Discussion}

The colour of all the isolates sporeballs was dark brown to black colour and did not vary much, while the shape was semi-circular to irregular. Therefore, the isolates could not be effectively classified into different groups on the basis of shape and colour. A significant variation was observed in length and breadth of the sporeball varying in a range of $16.2 \times$ 21.5 to $73.4 \times 92.4 \mu \mathrm{m}$ (Table 2 ). The Mp2 isolate was found to be larger with mean length and breadth of $73.4 \times 92.4 \mu \mathrm{m}$ followed by Mp3, Mp4 and Mp1isolate with sporeball size of $51.6 \times 58.8,37.0 \times 46.8$ and $16.2 \times$ $21.5 \mu \mathrm{m}$, respectively. In all the isolates sporidia were hyaline in colour and single celled but variation was observed in length. Maximum sporidial length $(16.1 \mu \mathrm{m})$ was observed in Mp2 isolate followed by Mp3 $(15.4 \mu \mathrm{m}), \mathrm{Mp} 4(15.1 \mu \mathrm{m})$ and Mplisolate $(14.4 \mu \mathrm{m})$ but no correlation was found between sporidial length and sporeball size of different isolates. The germination percentage of these isolates varied with maximum mean germination per cent of $\mathrm{Mp} 2$ isolate i.e. 
$52.24 \%$ followed $48.62,45.70$ and $40.54 \%$ respectively forMp1, Mp3 and Mp4 isolate.

Fischer and Holton (1957) reported that variation in sorus characteristics is common to several species and races of Tilletia. Bansal et al., (1984) observed variation in size of teliospores of Tilletia barclayana causing bunt of rice and this was influenced by environmental conditions. Accordingly, concluded from the above morphological studies that the variations in size of sporeballs, teliospores and sporidia among isolates might represent temporary response to environment and might not be inherently permanent. Morphological variability in spore size might be useful criteria for species delimitations within a genus of smut fungi which however, are not sufficient to elucidate variability within species. Pannu and Chahal (2000) reported that the teliospore germination in different isolates varied with the set of conditions under which they were produced and matured. Even all the sori collected from same location do not germinate at same time when kept under same set of conditions.

Pannu et al., (2002) reported that the germination might vary due to age, physiology or genetical reasons, thus these characters could not be considered as criteria to distinguish the isolates of Tilletia barclayana from each other. Meena et al., (2010) studied morphological, cultural and pathological variability in five isolates of $M$. penicillariae, collected from the four different agro climatic zones of Rajasthan and reported no variation in size of sporeball whereas size of the teliospores, length of sporidia and their germination percentage varied significantly among different isolates.

Variation was observed in the colony colour and growth of $M$. penicillariae on different media. It is evident from Table 3 that after one week, PDA enriched with $50 \mathrm{~g}$ pearl millet grains and $20 \mathrm{~g}$ sucrose showed the maximum growth of $3.20 \mathrm{~cm}$, followed by $3.03 \mathrm{~cm}$ growth in PDA enriched with $25 \mathrm{gL}^{-1}$ pearl millet grains and $20 \mathrm{gL}^{-1}$ sucrose. Further, $M$. penicillariae was also found to be fast growing on PDA enriched with $50 \mathrm{~g}$ pearl millet grain and $20 \mathrm{~g}$ sucrose than PDA enriched with $25 \mathrm{~g}$ pearl millet grain and $20 \mathrm{~g}$ sucrose after $2^{\text {nd }}$ and $3^{\text {rd }}$ week. The increase in pearl millet concentration in PDA+ sucrose media to $100 \mathrm{~g}$ was not found to be effectively increasing the mycelial growth. Least growth was observed in case of oat meal agar medium. It was found that PDA enriched with pearl millet grain@50 g and sucrose @ $20 \mathrm{~g}$ was better than PDA, Czapekdox and oat meal agar medium. According to Meena et al., (2010) glucose yeast extract agar medium was best for the growth of the M. penicillariae when compared to other medium i.e. potato agar, carrot agar, MEPA and YEPA. Although most species respond well to carbohydrates but variation within and among species was observed as which form of sugar is best. (Fisher and Holton, 1957).

Table.1 List of pearl millet hybrids, its parentage and general features

\begin{tabular}{|c|c|c|l|}
\hline S.No. & Hybrid & \multicolumn{1}{|c|}{ Parentage A×R } & \multicolumn{1}{c|}{ Features } \\
\hline $\mathbf{1}$ & $\begin{array}{c}\text { HHB 67 } \\
\text { Improved }\end{array}$ & ICMA843-22×H77/833-2-202 & $\begin{array}{l}\text { Extra early maturity, highly resistant to water stress and } \\
\text { downy mildew. }\end{array}$ \\
\hline $\mathbf{2}$ & HHB 197 & ICMA 97111 $\times$ HBL-11 & Early maturity, medium tall, long bristles, dark green leaves. \\
\hline $\mathbf{3}$ & RHB 177 & ICMA 843-22 $\times$ RIB494 & Early maturing, medium tall, cylindrical bristled earheads. \\
\hline $\mathbf{4}$ & HHB 226 & ICMA 843-22 $\times$ HBL-11 & Medium maturing, candle shaped bristled earheads. \\
\hline
\end{tabular}


Table.2 Morphological characteristics of different M. penicillariae isolates

\begin{tabular}{|c|c|c|c|c|c|}
\hline Isolate & $\begin{array}{c}\text { Size of } \\
\text { sporeball }(\boldsymbol{\mu m})\end{array}$ & $\begin{array}{c}\text { Colour of } \\
\text { Sporeboll }\end{array}$ & $\begin{array}{c}\text { Shape of } \\
\text { Sporeboll }\end{array}$ & $\begin{array}{c}\text { Size of } \\
\text { sporidia }(\boldsymbol{\mu m})\end{array}$ & $\begin{array}{c}\text { Germination } \\
\text { per cent }\end{array}$ \\
\hline Mp1 & $16.2 \times 21.5$ & Dark brown & Irregular & 14.4 & 48.62 \\
\hline Mp2 & $73.4 \times 92.4$ & Dark brown & Semi circular & 16.1 & 52.24 \\
\hline Mp3 & $51.6 \times 58.8$ & Black & Irregular & 15.4 & 45.70 \\
\hline Mp4 & $37.0 \times 46.8$ & Blackish brown & Irregular & 15.1 & 40.54 \\
\hline
\end{tabular}

Table.3 Colony diameter of $\mathrm{Mp} 2$ isolate on different media

\begin{tabular}{|l|c|c|c|}
\hline \multirow{2}{*}{ Medium } & \multicolumn{3}{|c|}{ Colony diameter (cm) } \\
\cline { 2 - 4 } & 1 week & 2 week & 3 week \\
\hline Potato Dextrose Agar (PDA) & 2.60 & 6.07 & 7.27 \\
\hline Czapekdox agar & 1.82 & 5.05 & 5.92 \\
\hline Oat meal agar & 1.02 & 2.85 & 4.75 \\
\hline PDA + PMG* 25 g + 20g sucrose & 3.03 & 6.29 & 7.82 \\
\hline PDA + PMG 50 g + 20g sucrose & 3.20 & 6.49 & 7.97 \\
\hline PDA + PMG 100 g + 20g sucrose & 2.62 & 6.09 & 7.42 \\
\hline
\end{tabular}

Table.4 Smut severity (\%) of different pearl millet cultivars inoculated with different $M$. penicillariae isolates

\begin{tabular}{|c|c|c|c|c|}
\hline \multirow{2}{*}{ Isolate of M. penicillariae } & \multicolumn{4}{|c|}{ Smut severity (\%) } \\
\cline { 2 - 5 } & HHB 197 & HHB 67 (Improved) & HHB 226 & RHB 177 \\
\hline Jaipur (Mp1) & 5 & 10 & 10 & 5 \\
\hline Hisar (Mp2) & 10 & 15 & 15 & 10 \\
\hline Gwalior (Mp3) & 2 & 5 & 2 & 1 \\
\hline Mandore (Mp4) & 0 & 5 & 5 & 1 \\
\hline
\end{tabular}

The results of virulence pattern observed are presented in Table 4. It is evident from the results that Mp-2 (Hisar isolate) was most virulent and exhibited 10,15, 15 and $10 \%$ smut severity on HHB 197, HHB 67 (Improved), HHB 226 and RHB 177, respectively in comparison to other three isolates viz., Mp-1, Mp-3 and Mp-4. Smut severity was maximum on HHB-67 Improved irrespective of any isolate inoculated. The smut severity was comparatively lesser on
RHB 177 irrespective of inoculation by any of the isolate. Studies on pathogenic variability suggested difference in the virulence among different isolates of M. penicillariae.

\section{References}

Ajrekar, S.L. and Likhite, V.N. (1933).Observations on Tolyposporium penicillariae Bref. (The Bajri Smut Fungus). Current Science, 1: 215. 
Bansal, R., Singh, D.V. and Joshi, L.M. (1984).Effect of Karnal bunt pathogen (Neovossiaindica) on wheat seed.Indian Journal of Agricultural Sciences, 54: 663-666.

Bhatt, R.S. (1946). Studies in Ustilaginales. The mode of infection of bajra plant (PennisetumtyphoidesStapf and Hubbard) by the smut Tolyposporium penicillariaeBref. Journal of Indian Botanical Society, 25: 163-186.

Fischer, G.W. and Holton, C.S. (1957).Biology and control of the smut fungi.Ronals Press Company. New York. pp. 622

Fuller, D. Q. (2003). African crops in prehistoric South Asia: a critical review. Progress in Africa Archaeobotany.Africa Praehistorica 15 series. Cologne: Heinrich-BarthInstitute, 239-271.

Meena, R.L., Mathur, A.C., Sobti, A.K. and Majumdar, V.L. (2010).Variability among Moesziomyces penicillariae
(Bref.)Vanky, the incitant of smut of pearl millet.Plant Disease Research, 25(1): 39-43.

Pannu, P.P.S. and Chahal, S.S. (2000).Variability in Tilletiaindica, the incitant of Karnal bunt of wheat. Indian Phytopathology, 53: 279-282.

Pannu, P.P.S., Kaur, G. and Chahal, S.S. (2002).Variability in Tilletiabarclayana, the casual organism of Kernel smut of rice. Journal of Mycology and Plant Pathology, 32: 6-10.

Ramakrishanan, T.S. (1963). Diseases of millets. Indian Council of Agricultural Research, New Delhi, pp 67-82.

SubbaRao, K.V. and Thakur, R.P. (1983).Tolyposporiumpencillariae, the causual agent of pearl millet smut.Transactions of the British Mycological Society, 81: 597-603.

Thakur, R.P. and King, S.B. (1988). Smut disease of pearl millet. Information Bull.No.25, pp.17, ICRISAT, India.

\section{How to cite this article:}

Annie Khanna, Kushal Raj, Pooja Sangwan and Narender Singh. 2018. Morphological, Cultural and Pathological Variability of Moesziomyces penicillariae (Bref) Vanky isolates, the Incitant of Pearl Millet Smut. Int.J.Curr.Microbiol.App.Sci. 7(06): 3881-3885. doi: https://doi.org/10.20546/ijcmas.2018.706.457 